\title{
Environmental Issues in China
}

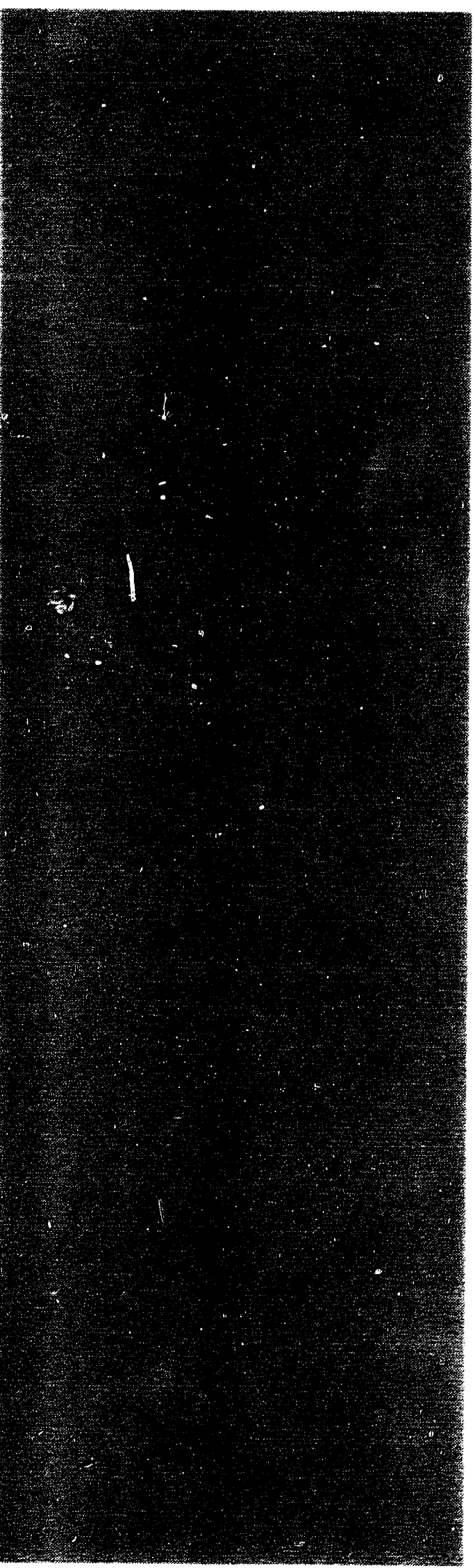

\section{Los flanos}

Los Alamos National Laboratory is operated by the Unitersity of California for the United States Department of Energy under contract W-7405-ENG-36 
An Affirmative Action/Equal Opportunity Employer

This report was prepared as an account of uork sponsored by an agency of the

United States Government. Neither The Regents of the University of California, the United States Gocernment nor any agency thereot, nor any of their employees, makes any warranty, express or implied, or assumes any legal liability or responsibility for the accuracy. completeness, or usefulness of any information, apparatus, product, or process disclosed, or represents that its use would not infringe privately owned nghts. Reference herein to any specific commercial product, process. or seritce by trade name, trademark, manufacturer, or otheruise, does not necessarily constitute or imply its endorsement. recommendation, or fazoring by The Regents of the University of California, the United States Government, or any agency thereof. The iveus and opinions of authors expressed herein do not necessarily state or reflect those of The Regents of the University of California, the United States Government, or any agency thereof 


\section{Environmental Issues in China}

\section{P. S. Travis}




\section{CONTENTS}

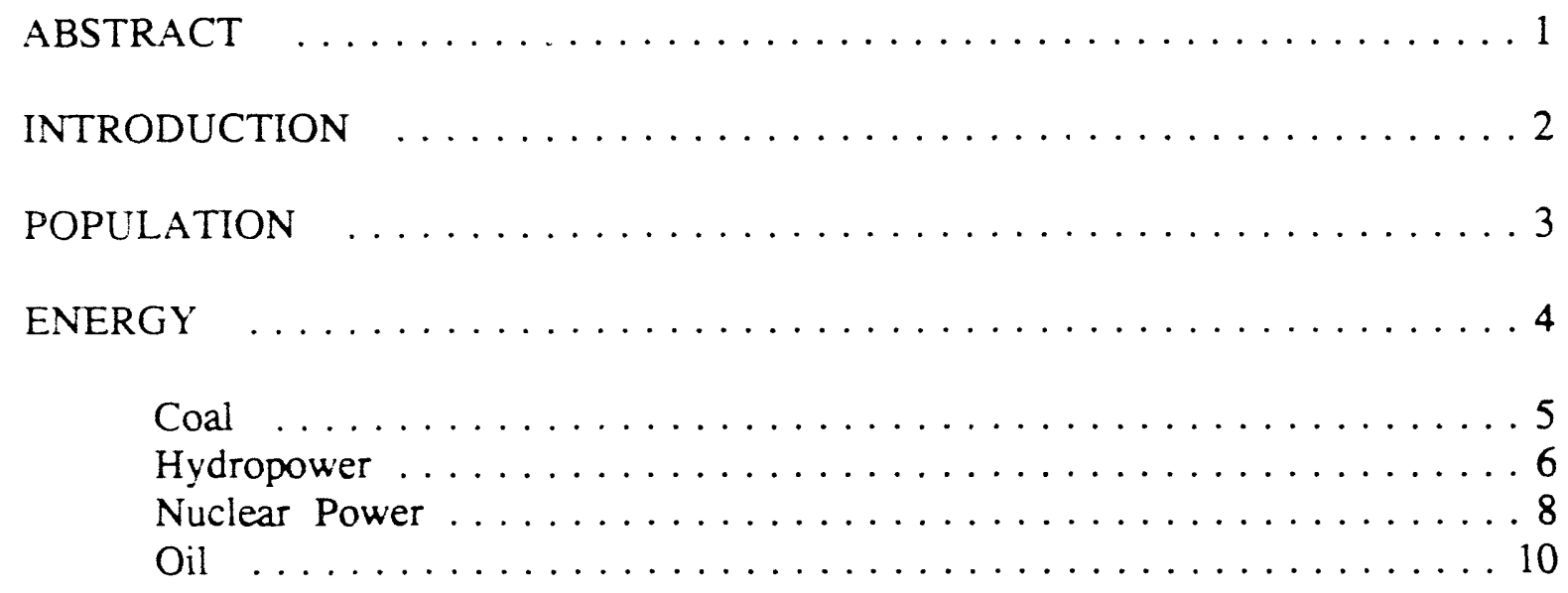

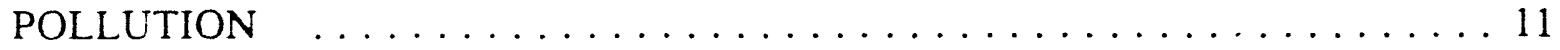

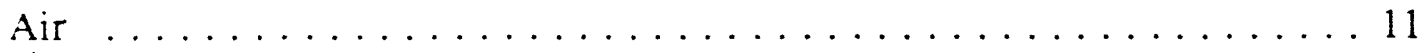

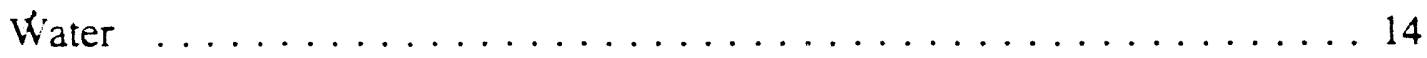

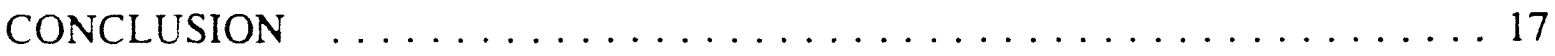

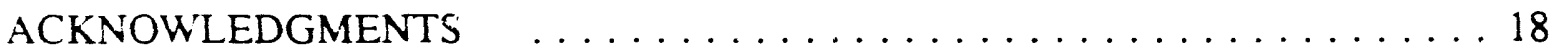

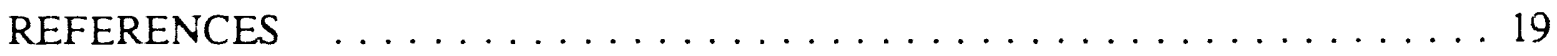




\title{
ENVIRONMENTAL ISSUES IN CHINA
}

\section{by}

\author{
P. S. Travis
}

\begin{abstract}
Global concern about the environment is increasing, and the People's Republic of China (PRC) is not immune from such concerns. The Chinese face issues similar to those of many other developing nations. The US Department of Energy is particularly interested in national and world pollution issues, especially those that may infringe on other countries' economic growth and development. The DOE is also interested in any opportunities that might exist for US technical assistance and equipment in combatting environmental problems. Our studies of articles in the China Daily, an English-language daily newspaper published by the Chinese government, show that population, pollution, and energy are major concerns of the Chinese Communist Party. Thus this report emphasizes the official Chinese government view. Supporting data were also obtained from other sources.

Regardless of the severity of their various environmental problems, the Chinese will only try to remedy those problems with the greatest negative effects on its developing economy. They will be looking for foreign assistance, financial and informational, to help implement solutions. With the Chinese government seeking assistance, the United States has an opportunity to export basic technical information, especially in the areas of pollution control and monitoring, oil exploration methods, oil drilling technology, water and sewage treatment procedures, hazardous waste and nuclear waste handling techniques, and nuclear power plant safety procedures. In those areas the US has expertise and extensive technical experience, and by exporting the technologies the US would benefit both economically and politically.
\end{abstract}




\section{INTRODUCTION}

The People's Republic of China (PRC) is divided into two environmental zones: outer China and agricultural China (Fig. 1). Outer China is vast, remote, and thinly populated, with a topography of high plateaus, towering mountains, and imposing deserts. The three major physiographic regions-Xizang, Xinjiang, and Inner Mongolia-constitute over half of China's total land area but contain less than $4 \%$ of its total population (English, 1984, p. 349). The population of outer China consists mainly of non-Chinese ethnic groups such as Tibetans, Muslim nomads, and Mongols. These ethnic minorities account for about 7\% of the PRC's population (MacDougall, 1990, p. 16). Outer China is endowed with numerous largely untapped natural resources such as chromium, uranium, copper, iron, coal, manganese, and oil ("Chinese Mining," 1983, p. 73). The incessant hostility of the people of outer China to the Chinese and the development difficulties in these extreme environments impede modernization efforts.

Agricultural China is the heartland of China's economy and society. It has less than one half of China's total land area but more than $95 \%$ of its total population (English, 1984, p. 352). Population densities can average as high as 2500 people per square mile (English, 1984, p. 352). This area contains the industrial centers and the large cities-Beijing, Shanghai, and soon Hong Kong-and is the country's breadbasket. Agricultural China produces virtually all the food for China's population of more than one billion (English, 1984, p. 352).

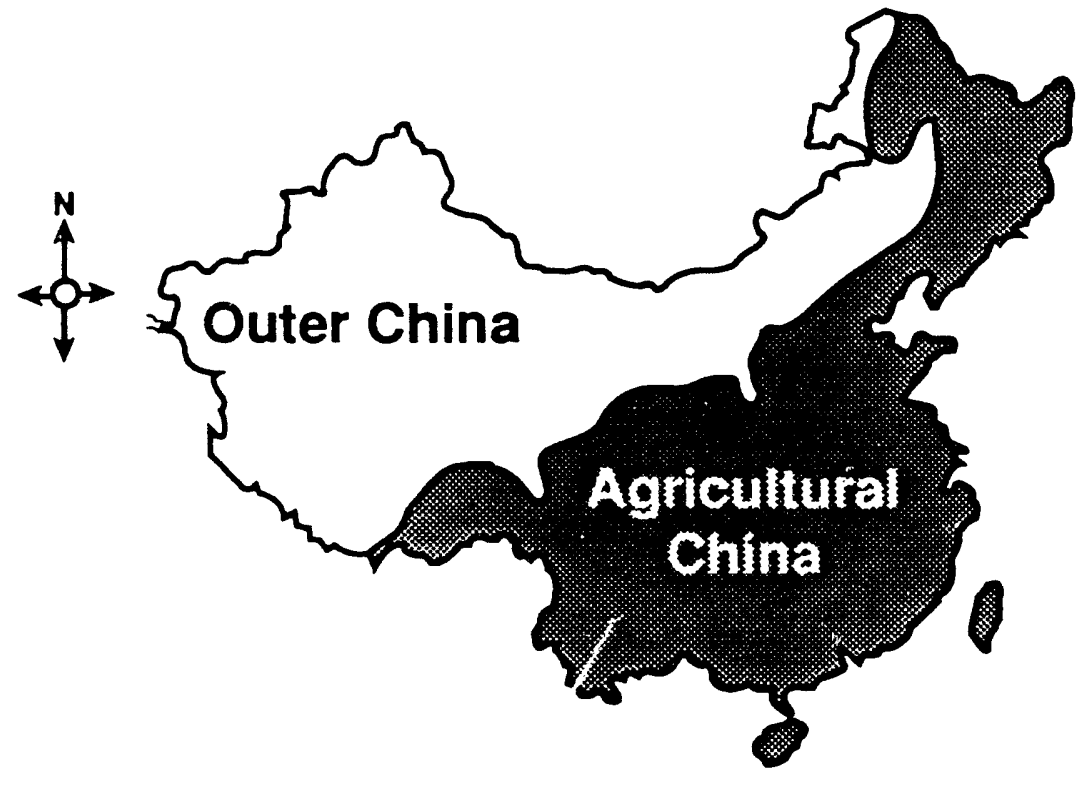

Fig 1. Environmental zones.

Based on: World Regional Geography, P. W. English, copyright $\bullet 1977$ by John Wiley \& Sons, Inc., p. 348 . Reprint by permission of John Wiley \& Sons, Inc. 


\section{POPULATION}

Today's world population numbers more than five billion people; in the next century the world population will double, with a growth rate of 90 million a year ("Two Ways to Cope," 1988, p. 943). About $90 \%$ of the growth will occur in the developing countries (Toufexis, 1989, p. 48). The problem with such massive growth is that many of the developing countries' populations are already straining their nations' abilities to provide the bare necessities like housing, fuel, and food.

China is the most populous country in the world, and ultimately no problem may be more threatening to China's environment than its population. For example, China's population is four times that of the US but its agricultural area roughly equals that of the US (English, 1984, p. 332). China has $20 \%$ of the world's population but only $7 \%$ of the world's arable land (Chua-Eoan, 1989, p. 50). In 1971 the government of China forced its people into participating in a population planning effort by launching its "One-Family, One-Child" policy. The goal of this policy was to contain the population to 1.2 billion by the year 2000. To achieve this goal the government offered incentives such as monthly stipends, better housing, free education, and better health care to couples who had only one child. Conversely, the government penalized couples who had more than one child. The penalties ranged from job dismissal and fines (up to a year's wages) to more distressing actions such as forced abortions. However, only $19 \%$ of China's couples have one child (Toufexis, 1989, p. 50). The discrepancy between government policy and actual public participation is a result of urban vs. rural cultures. The policy is easier to enforce in urban areas than in rural areas where there is strong social support to have large families because children are a source of labor and a hedge against poverty in old age. Farmers make up about $80 \%$ of China's work force (English, 1984, p. 352).

China's population control efforts have produced some results: the annual population growth rate was cut in half, from approximately 3\% in 1979 to $1.4 \%$ in 1989 (Toufexis, 1989, p. 50), but the Chinese stili face an enormous increase in population. It is estimated that instead of being at 1.2 billion (Fig. 2), China will be at 1.27 billion by the year 2000 (Toufexis, 1989, p. 50). More than 20 million people are born every year, but the net annual increase is around 17 million ("Census Finds 1.16 Billion; Annual Rise 17 Million," 1990). More than 50,000 babies are born daily. Those who were born between 1965 and 1975-some 258 million people -comprise the single largest population group in China. This group constitutes $22 \%$, or nearly one quarter, of the total Chinese population (World Resources, 1990, p. 55). The effect of this generation, as it reproduces, and the responsibility for the elderly (the average life span has increased from 35 in 1949 to the present age of 68) will be staggering. 


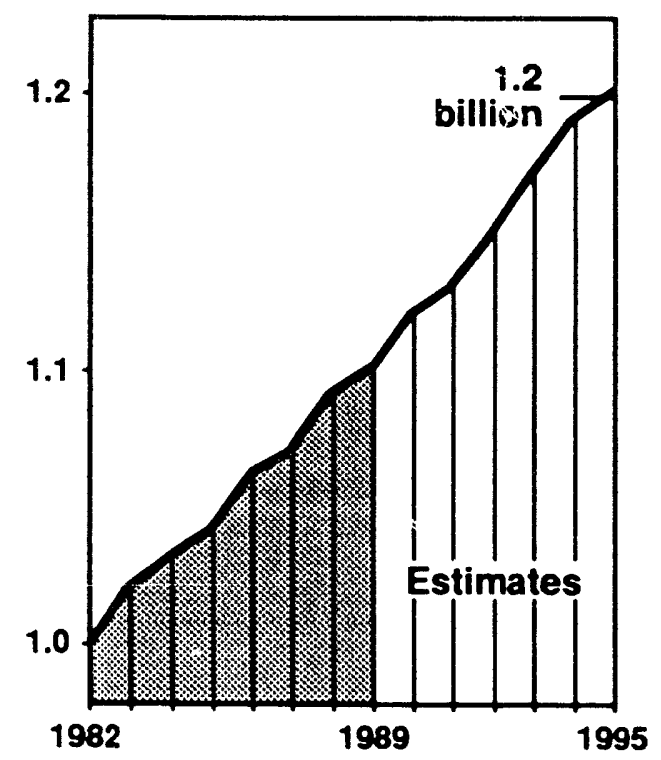

Fig. 2. China's projected growth (in billions).

Source: Center For International Research, US Census Bureau.

\section{ENERGY}

Energy sources are overburdened. Shortages of energy and key natural resources have troubled China for years and will remain a major problem throughout the 1990s. The government expected the country's industrial growth to be about $6 \%$ in 1990, but energy growth was only about 3\% (Chengwen, January 1990). Such shortages are reducing China's productivity by $20 \%-30 \%$ a year. Beijing's problems illustrate China's overburdened energy resources. Beijing is short $400,000-500,000 \mathrm{~kW} \cdot \mathrm{h}$ of energy a day (Hong, 1989). The government directs power to key users like foreign embassies, state offices, military headquarters, and hospitals. The rest of the city experiences frequent blackouts.

The distribution of energy in China is geographically disproportionate. The better-developed coastal areas are short of power while the vast West (outer China) uses only a fraction of its energy resources. Difficulties arise in transporting energy resources from where they are found to where they are needed. 
Energy resources in China are poorly managed and used inefficiently. Because China is a developing nation, it has little experience managing and efficiently using resources. The Soviet Union has the least energy-efficient economy in the world, and the Chinese economy is only slightly more efficient than the Soviet's (World Resources, 1990, p. 147). China's energy planning has focused on expanding conventional energy supplies rather than on improving energy efficiency. Energy consumption has risen as economic activity increased and as populations have grown. One problem is that many Chinese resources are priced too low, a situation that leads to inefficient allocations. For example, coal is abundant and priced below the market value, so there is no incentive to conserve (Carpenter, 1990, p. 785) or to try and use it more efficiently.

China in 1980 signed technology-transfer contracts with two US firms to acquire two large energy-efficient thermal generators (Kan, 1990). The US can help the Chinese apply energy-efficient technologies that promote economic growth and at the same time keep energy demands relatively low. Large amounts of capital and skilled management are required to shift to these energy-efficient technologies and to build and maintain the needed infrastructure. Strong evidence suggests that it would cost China less, in the long run, to take the energy-efficient approach than it would to continue on its current path (World Resources, 1990, p. 147).

Currently, China's per capita energy consumption is only one third of the world's per capita energy consumption (JPRS-TND-88-017, 1988, p. 7). The average yearly electricity consumption per person in China is only about $300 \mathrm{~kW} \cdot \mathrm{h}$. By the year 2000 , the figure should rise to over $1000 \mathrm{~kW} \cdot \mathrm{h}$ ("Nuclear Plant Makes Energy and Aids Economy," 1989). Thus, expanding power-generating capacity remains a top priority of the Chinese government. As stated in China's Eighth Five-Year Plan, projected electricity output for the years 1995 and 2000 are 810 billion $\mathrm{kW} \cdot \mathrm{h}$ and 1,100 billion $\mathrm{kW} \cdot \mathrm{h}$ respectively. This increase is about $5.7 \%$ in annual growth rate, which is about the same growth rate for their GNP (gross national product) (Naughton, 1991, p. 9). This growth should greatly intensify pollution and its numerous effects.

\section{Coal}

Coal is China's major energy resource, constituting over $70 \%$ of the country's energy production and consumption (JPRS-TND-88-017, 1988, p. 7). The government predicts the emphasis on coal will remain unchanged for at least the next decade. In 1989 coal output was 1.04 billion tons, making China the world leader in coal production and consumption (Hongqi, 1990). The government predicts by the years 1995 and 2000 coal output will be 1.2 billion tons and 1.4 billion tons, respectively (Naughton, 1991, p. 9). The Chinese consume $24 \%$ of the world's coal resources; the US comes in second at $19 \%$ (World Resources, 1990, p. 142). The Chinese government estimates China has 840 billion tons of coal reserves, which should last hundreds of years (JPRS-TND-88-017, 1988, p. 7). Ningxia, Shaanxi, Shanxi, and Inner Mongolia have immense coal reserves. In fact, those four areas have approximately $75 \%$ of the country's total reserves (Hongqi, 1990)(Fig. 3). 
Despite the abundance of coal, there are problems with its use. Plagued by lack of capital investment, skewed pricing, transport bottlenecks, and inefficient utilization, the coal sector has not been able to keep pace with overall economic growth. Businesses and industries around the country sit idle several times a week due to lack of electricity while large amounts of coal pile up outside mines. The coal mines in China are concentrated in the north and northwest, but the major consuming centers are in the south and east. The journey east from the coal fields entails lengthy and expensive transport by rail and water. China's coal transportation accounts for $40 \%$ of the total railroad volume (JPRS-TND-88-017, 1988, p. 7). This situtation has caused a serious strain on the coal-carrying capacity of the rail system. To try and alleviate the coal shortage, China is planning to build more railroads and to acquire western equipment and technology. Much of its rail system is single track and unelectrified. Over half of the locomotives are steam-driven (Huang, 1991, p. 23). It is estimated that China requires another $11,000 \mathrm{~km}$ of railroad to begin to alleviate the bottlenecks. The Chinese government plans to spend about $\$ 1000$ million on coal extraction and transportation machinery in the 1990s (McGregor, 1991, p. A8).

Futhermore, coal is a big polluter. (The overall topic of pollution will be discussed in more detail in the section entitled "Pollution".) Burning coal causes $80 \%$ of China's air pollution (JPRS-TND-88-017, 1988, p. 7). The indigenous coal is high in sulfur, so when it is burneci it gives off $\mathrm{SO}_{2}$, a component in acid rain; furthermore, burning any fossil fuel (coal, oil, and natural gas) in large quantities releases $\mathrm{CO}_{2}$, one of the agents that causes the greenhouse effect, or global warming. The coal in China also has a high fluorine count, so using it in homes for cooking and heating causes a disease called fluorine toxicosis, which affects bones and teeth. More than 40 million Chinese suffer from fluorine toxicosis symptoms, and another 200 million are likely to contract the disease in the next few years (Baoxia, 1990). Fluorine content in the coal can run as high as $2000-3000 \mathrm{mg}$ per kilogram of coal; the international standard for safe use is $80 \mathrm{mg}$ fluorine per kilogram of coal (Baoxia, 1990). In many homes, especially in rural China, cooking is done on stoves without chimneys. Some homes do not even have stoves; the people just pile the coal on the dirt floor inside a room and light it for cooking and heating. Other ecological hazards from mining coal include landslides, mudflows, and soil erosion.

\section{Hydropower}

The major rivers in China are the Yellow, the Yangtze, and the Xi Jiang. The upper reaches of those rivers are suitable for hydropower (Fig. 3). It is estimated that China's hydropower potential is 378 million $\mathrm{kW} \cdot \mathrm{h}$, with two thirds of that in southwest China (Fig. 3) (Xiang, 1990). In that area, coal is scarce but water is plentiful. Nonetheless, only $9 \%$ of the hydropower resources have been tapped (Xiang, 1990). Building hydropower stations is a long-term and expensive project. Chinese experts say it can take anywhere from 6 to 12 years and cost up to several million dollars to build a large hydropower station (Xiang, 1990). The Three Gorges Project, for example, is the 
largest dam project ever considered in China or in the world. The dam, if built, will be $185 \mathrm{~m}$ high and $2.8 \mathrm{~km}$ wide. Consiruction time is estimated at 20 years. The hydropower generated from that project would be the greatest in the world and would augment China's electrical capacity by up to $40 \%$. Although the Three Gorges Project has become one of China's most valued symbols of development and the Chinese press raves about the project, it is by no means certain the dam will even be built. The dam threatens to destroy animal and plant life along much of the river, and downstream it would damage agriculture and fisheries. Upstream it would create flooding that would drive more than a million peasant farmers from their homes (Pearce, 1990, p. 11).

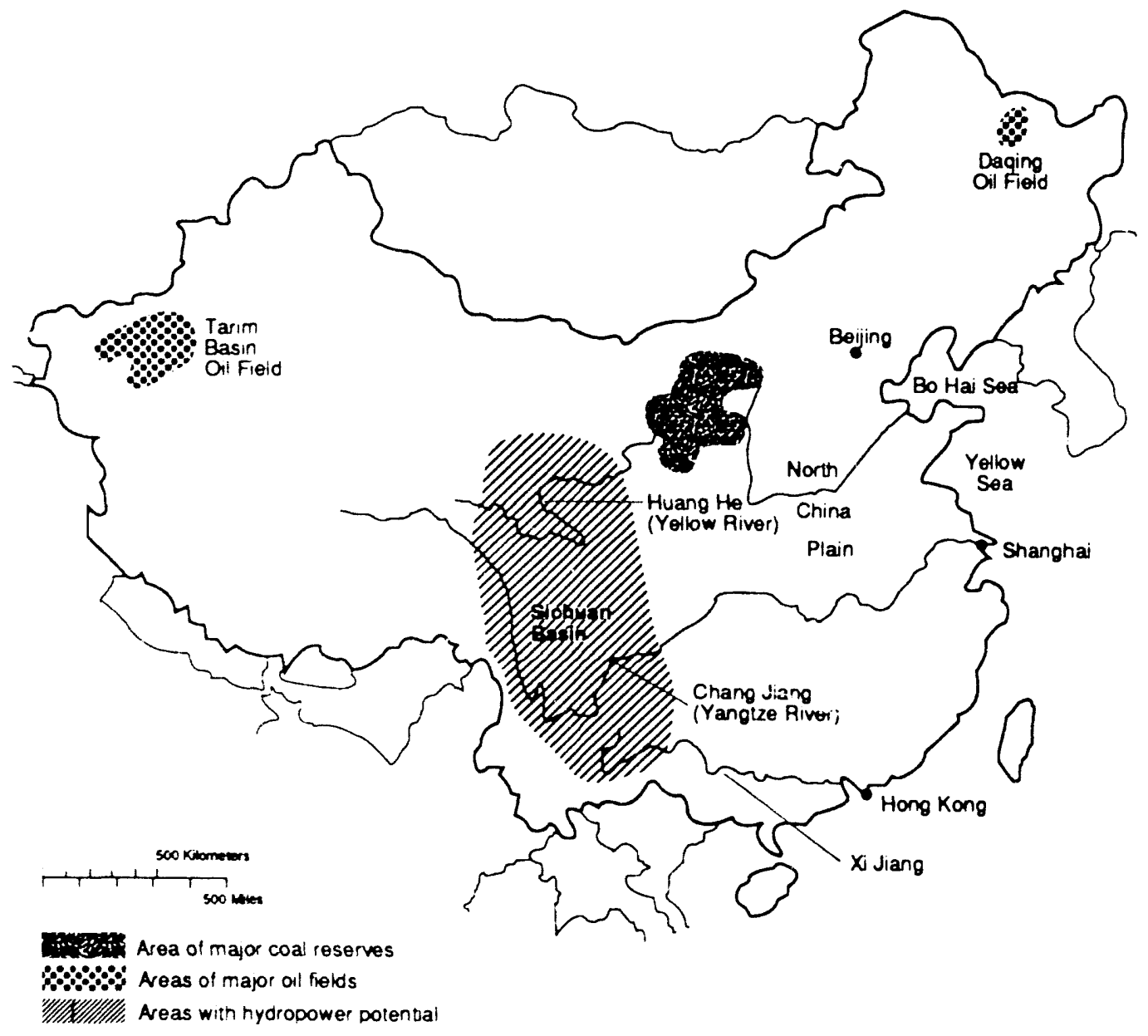

Fig. 3. Location of 3 major energy resources. 
Like coal, there are problems with using hydropower. Southwest China (Fig. 3) is far from the east coast, where the majority of the power is needed, so transportation entails considerable expense and inefficiency. As mentioned above, there are also environmental predicaments when one builds hydropower dams. Dams have long-term effects on rivers, changing the chemical composition of the water and thus damaging ecosystems. Dams also direct river flow and impede river transportation (Ember, 1990, p. 13).

\section{Nuclear Power}

Nuclear power is China's hope for the future. Efficient and safe nuclear power plants (NPPs) could provide abundant electricity without spewing pollutants into the atmosphere. The two NPPs being built are civilian reactors. The Chinese are in the early stages of developing their nuclear power program and have no major reactors running. They do have a small nuclear reactor $(5,000 \mathrm{kWe})$ located in a :ortheast suburb of Beijing that produces central heating for the area.

The two major plants under construction are Qinshan NPP and Daya Bay NPP. The former, south of Shanghai, should start by December 1991. It is about $80 \%$ China's own effort, a source of pride for the Chinese (Zai, 1989). The Chinese National Nuclear Corporation is responsible for everything associated with Qinshan's development, from reactor supplier to architect engineer ("World List of Nuclear Power Plants," August 1990 , p. 65). When running, the pressurized light-water reactor will produce 300,000 k'Ve (Zai, 1969). The Daya Bay NPP near Hong Kong will have two pressurized light-water reactors, each running at a capacity of $900,000 \mathrm{kWe}$ (FBIS-CHI89-009-S, January 1989, p. 24). The first reactor should start by October of 1992; the second by July of 1993. This NPP is being constructed jointly with foreign firms. The Framatome Company of France supplied the reactor technology; General Electric Company of Great Britain supplied the generators; they also supplied architectural engineers along with Electicite de France. China, France, and Japan jointly work on the construction of the facility ("World List of Nuclear Power Plants," August 1990, p. 65). Chinese officials maintain that completion of these reactors will help relax strained power supplies on the east coast.

The Chinese government plans to build more NPPs along the east coast to compensate for lack of coal and hydropower energy. According to Premier Li Peng, China plans to build four large and medium-sized NPPs by the end of the century with a combined power of up to 10 million kWe ("Nuclear P!ant Makes Energy and Aids Economy," 1989). The official government line is that nuclear power will help China supply its energy-hungry economy. However, the Chinese are also building NPP for the prestige. To be able to build NPPs independently from foreign assistance and master advanced nuclear technology is an achievement the Chinese consider extraordinary. Having NPPs would allow the Chinese to feel at par with developed countries. Furthermore, the Chinese consider NPPs and the related technologies big export 
potentials. They would like to export their knowledge to the Third World. Whether building all these NPPs will relieve China's energy shortage is debatable. Many nuclear experts feel that building and operating all the planned NPPs will overwhelm the Chinese and that they will not even be able to keep them running, much less distribute the power.

There are problems with nuclear power. As mentioned earlier, the Chinese are in the early stages of developing their civilian reactor program. They have military experience with nuclear power, having detonated their first nuclear bomb in 1964. Developing nuclear power is expensive and it requires scientific and technological knowhow. China's financial resources, foreign exchange reserves, and technological level are limited (FBIS-CHI-90-067-S, 1990, p. 18). Therefore, China will be taking sniall steps in developing its nuclear power program.

The US has extensive experience with nuclear power and over 100 NPPs in operation. Nuclear power is the second largest source of electricity, after coal, in the US. Thus, nuclear power is another area where the US can export some of its reactor and nuclear safety technclogies. The US has a series of physical barriers used on all its reactors to prevent radioactive material from reaching the environment. The US also has done lengthy research on a newer generation of reactors that contain passive safety systems. These systems substitute natural forces like gravity and convection to protect the vast network of systems that run nuclear plants. General Electric Company and Westinghouse Electric Corporation are involved in the development of advanced versions of light-water reactors that incorporate the passive emergency cooling features (World Resources, 1990, p. 152).

Since China does not have any major civilian reactors running, most of its nuclear waste is generated by the military, laboratories, and hospitals ("China Says Nuclear Accidents Killed 20," 1989). China is building storage facilities for radioactive waste from NPPs: in fact, facilities have been built in 12 provinces and are planned for eight others ("China Says Nuclear Accidents Killed 20," 1989). The Chinese reportedly plan to establish four regional disposal facilities, one each in eastern, southern, northwestern, and southwestern China.

In the past, the Chinese have been secretive about accidents related to radioactivity. However, last fall China issued a statement about some of its nuclear accidents. The Chinese reported 1200 people were injured and 20 people were killed between 1980 and 1985 because of careless handling of radioactive materials. The Chinese attribute those accidents to incompetent managers and managers' and workers' ignorance about the dangers of nuclear materials ("China Says Nuclear Accidents Killed 20,"1989). The report gave an example of a carpenter at an electric equipment plant who stole a lead container full of radioactive ${ }^{60} \mathrm{Co}$, dumped the ${ }^{60} \mathrm{Co}$ out, and sold the container; no deaths or injuries were reported ("China Says Nuclear Accidents Killed 20," 1989). 
Oil is currently China's least developed energy source (FBIS-CHI-89-009-S, 1989, p. 24). Although China has some notable oil fields, it lacks funds for capital construction and suffers from frequent electrical shortages that directly hamper oil production. Theft and sabotage are also a problem. In the first half of 1989 , a total of 803,000 barrels of oil were stolen and some production equipment was damaged ("Oil Output Increases But Industry in Trouble," 1989). China's recoverable barrels from all her fields in 1987 were estimated to be at 2,451 million tons (World Resources, 1990, p. 321). In comparison, the US's recoverable barrels in 1987 were approximately 4,385 million tons and Saudi Arabia, the world's number one producer, yielded 22,712 million tor: (World Resources, 1990, p. 320-321).

China's major oil fields are in the northeast (Fig. 3). The largest is Daqing oil field in Heilongjiang province. It is estimated that Daqing's recoverable barrels will reach 365 million by the end of this year ("Oil Produced," 1990). Endicott field, the ninth largest oil field in North America, has 300 to 350 million recoverable barrels (Lee, 1988, p. 865). The Chinese, with Western assistance, are exploring extensively for more oil reserves (as much as they can afford it). They are especially looking west and offshore.

Billions of yuan (5 yuan are approximately equal to one dollar) are being spent on oil exploration in the basins in Xingiang Province in northwest China. The Tarim basin (Fig. 3) is the most promising oil production zone in the western region. However, its high dry desert, extreme temperature ranges $\left(20^{\circ} \mathrm{F}-126^{\circ} \mathrm{F}\right)$, poor infrastructure (virtually no roads), majority ethnic population (Muslim), and distance from eastern provinces and industries make the area difficult and expensive to drill for oil. So far there has been no foreign participation in the Tarim basin region except for a few World Bank loans (Vernor, 1990, pp. 6-12). The Chinese realize this area is too expensive to develop by themselves and are considering enlisting the aid of foreign oil companies. In fact, British Petroleum has petitioned the Chinese government to open the area up to foreigners. The Chinese need capital and advanced technology to begin to tap the Tarim basin's potential. The cost to drill in the basin is estimated to be $\$ 850$ per foot (Vernor, 1990, pp. 6-12). The Tarim basin is about the size of Texas and the Chinese estimate there are between 75-180 million recoverable barrels. The international oil community has a more conservative estimate of 35-90 million recoverable barrels (McKenzie, 1990). The Chinese believe $25 \%$ of their total oil reserves are located there (Hongqi, 1990).

The Bo Hai Sea, the Yellow Sea, and the South China Sea are the sites of the greatest concentration of offshore oil exploration (Fig. 3). The Chinese rely heavily on foreign help in such drilling. They do not have the technical expertise and capital to build a modern offshore oil platform. Western companies have invested a total of $\$ 2.7$ billion in China's offshore oil development since 1978 in the biggest business venture between capitalists and Chinese Communists (Tyson, 1990, p. 4). Only a few companies 
have discovered oil and expect to recover their exploration costs. Key countries who assist China with its offshore drilling are Japan, France, the United States, Great Britain, and Norway.

Exploring and drilling for oil, especially offshore drilling, can damage the surrounding environment. Such activity brings with it thousands of workers and all the apparatus they use. Oil facilities can cover many acres, and no matter how careful the workers are, the drilling complex is too large to avoid affecting the environment. Where there are wells, there is dumping of sewage, toxic waste, and frequent oil spills. One oil spill can cause numerous problems among marine organisms, including changes in feeding and reproductive patterns and abnormal behavior and growth.

Finally, most of the facilities the Chinese use to process their natural resources and raw materials into energy or other end products are of 1950s technology. The inadequate, inefficient equipment wastes $10 \%$ of the total power produced every year and pollutes the environment (Chengwen, July 1990).

\section{POLLUTION}

Local governments intensify pollution in China. Eager for quick benefits, they neglect consequences and deveiop their economies at the expense of the environment. The provincial governments have urged local governments at all levels to plan and enforce regulations to protect the environment and to control pollution.

\section{Air}

Coal's dominance as an energy source makes it one of China's biggest air polluters, and the country's reliance on coal is expected to increase. As stated earlier, $80 \%$ of China's air pollution is caused by coal. Particulates from burning coal account for $73 \%$ of the 23 million tons of particulate discharged in China's air every year (Hanchen, 1988, p. 37). Nine out of ten Chinese cities' air quality is below the nation's minimum standard, which itself is the lowest level approved by the World Health Organization. In July 1988 the air above Benxi, in northeast China, was so dirty that the city was invisible on satellite photography ("Pollution in Asia," 1990, p. 20).

Coal is also the source of $90 \%$ of the 14.6 billion tons of $\mathrm{SO}_{2}-\mathrm{a}$ main component of acid rain-discharged annually in China (Hanchen, 1988, p. 37). Typically, rainfall with a $\mathrm{pH}$ value of less than 5.6 is called acid rain. It affects humans, plants, buildings, and vehicles. It washes away forest soil, depriving the trees of nutrition, and activates aluminum ions in the soil which then poison the plants' root systems. Acid rain slows growth rates, lowers plants' resistance to insect attack, and eventually kills the plants (Hanchen, 1988, p. 37). After vegetation is destroyed, landslides, mudflows, and soil erosion are more likely to occur. 
In China, acid rain is usually thought to be closely related to industrialization, topography, weather, and poor-quality fuel. It is easily formed in basins and valleys where the climate is warm, moist, and cloudy and where there is hardly any wind. The acidity is stronger in the urban areas and in the winter months.

In the highly populated southwest provinces of Sichuan, Guizhou, and Guangxi, the average annual rain $\mathrm{pH}$ is less than 5.0-the worst recorded levels of acid rain in China (JPRS-CST-89-017, 1989, p. 28). In fact, Sichuan is the most populous province in China. Acid rain has slowly destroyed the area's forests; for example, in Sichuan the forest area has dropped from $20 \%$ of the province to $13 \%$ over the past 30 years ("Pollution Worsening in Sichuan," 1989). In a 6000-ha forest in Sichuan, almost all of the pine trees have died (Bian Yi, 1989). Local farmers are growing fewer kinds of vegetables and their harvests are decreasing. Furthermore, acid rain costs these provinces extra in maintenance and repairs because rust must be removed from their bridges, buses. streetlights, etc., and then everything has to be repainted.

Coal also gives off $\mathrm{CO}_{2}$ when it is burned. As stated earlier, $\mathrm{CO}_{2}$ is one of the many agents that cause global warming or the greenhouse effect-a phenomenon that causes the gases in the atmosphere to change. Muny scientists believe it may lead to global climate change. Whenever any wood or fossil fuels are burned, large amounts of $\mathrm{CO}_{2}$ are given off (Lemonick, 1989, p. 37). As China continues to develop, its coalburning power plants and factories will release $\mathrm{CO}_{2}$ at a rate faster than the vegetation and ocean, which absorb the gas, can handle it (Bian Yi, 1989).

The majority of China's air pollution is caused by coal smoke. In 1952, coal pollution killed about 4000 people in northern China (JPRS-TND-88-017, 1988, p. 8). The Chinese refer to this incident as "London Smog" after similar occurrences in London during the early 1950s. Currently, during high-temperature periods in China, coal-smoke pollution in many cities in northern China has reached the preliminary level of the "London Smog" incident (JPRS-TND-88-017, 1988, p. 8). The greenhouse effect has become a concern to the Chinese because they fear it will cause the average temperature to rise, and as a result, regions like northern and northwest China, which are traditionally dry regions, will become drier.

Since the major source of US energy comes from coal, the US could have an important role with helping the Chinese adapt some $\mathrm{SO}_{2}$ and $\mathrm{CO}_{2}$ emission controls. The US has helped China to some extent with its air pollution problems. In May of 1990 the Trans-America Chemical Corporation, a US firm, transferred technology on controlling acid pollution to China via the US/SHAXI Import/Export Corporation (Trans-American Chemical Corporation, 1989, p. 66). The University of Florida and Fudan University in Shanghai are involved in a joint air monitoring study for the city of Shanghai. The University of Florida supplies the air sampling devices and the students and researchers at Fudan University analyze the samples and diagnose the problems. 
Coal-burning power plants in the US are required to meet emission standards, and they meet them in several ways. Many power plants in the US use low-sulfur coal or "washed" coal, which emits fewer pollutants. US power plants also install scrubbers in the smokestacks, which remove $\mathrm{SO}_{2}$ from the flue gas of coal power plants. Scrubbers can remove up to $90 \% \mathrm{SO}_{2}$ in power plant emissions (World Resources, 1990, p. 206). Many coal power plants in the US use alternative burning processes, which also reduce emissions (Steger and Bowermaster, 1990, p. 81). Two efficient low-emissions means of generating electricity from coal are fluidized-bed combustion and coal gasification.

In fluidized-bed combustion, a strong upward current of air suspends crushed coal mixed with a "bed" of limestone particles in a furnace. The limestone reacts with and removes more than $90 \%$ of the sulfur in the coal, producing a benign dry waste that can be used as a construction material (World Resources, 1990, p. 206). In coal gasification, coal is not burned directly but is first converted into a clean-burning synthesis gas, which is then used in an efficient combined-cycle gas-turbine system. Tests on these systems show that about $95 \%$ of the sulfur from the synthesis gas is removed before burning (World Resources, 1990, p. 206). Furthermore, the US has carried out extensive research and development on new technologies designed to remove $\mathrm{SO}_{2}$ and other pollutants while boosting energy efficiency on fossil-fuel electrical generation plants. These technologies are referred to as clean coal technologies (World Resources, 1990, p. 143). These "clean coal technologies" control pollution in the combustion process (Steger and Bowermaster, 1990, p. 81).

Choking dust is a type of air pollution the Chinese know well. People all along the Inner Mongolian border and as far away as in Beijing have been faced with choking dust. The encroachment of the Gobi Desert, which is 150 miles from Beijing, is the cause. Beijing's Capital Airport has been known to close for hours due to major dust storms. Furthermore, women and children with brightly colored scarfs tied over their faces to protect themselves from the dust are a common sight in the capital.

The choking dust is a result of desertification, a process in which the land loses its vegetation and becomes a barren wasteland. In China, desertification is a result of low rainfall, extreme population pressures, and the destruction of vegetation. Desertification has increased the amount of dust and particulates in the air. The Chinese are being threatened by a desert that is spreading at a rate of 600 sq. mi. a year (Elmer-Dewitt, 1989. p. 71). However, the Chinese have thought of a relatively simple solution -the "Great Green Wall." It consists of planting grasses, shrubs, and trees along their 4350mile northern border (Elmer-Dewitt, 1989, p. 71). This project has been in progress for the past 13 years. About 9 million hectares were planted in trees in the northern provinces from 1978 to 1989, pushing the vegetation coverage in those areas from $5 \%$ to 7\%. Two million hectares has also been planted in grasses (FBIS-CHI-90-044, 1990, p. 37). In Beijing, people have planted trees along the roads and around fields. $f$ bird's-eye view of the city shows the five main highways lined with trees. Today, $20 \%$ of the suburban county of Beijing is covered with forest, compared with early 1950 s forestation, when 
only $1 \%$ of the county had trees (Cankao, 1990, p. 48). These examples show positive results to the "Great Green Wall" program; nevertheless, the loss of China's forests continues. Some experts even believe that about half the trees planted in official statistics are in fact imaginary, and only $40 \%$ of those actually planted survive (Ehrlich and Ehrlich, 1990, p. 116). It has been reported that annual consumption of wood for building, paper, and fuel was $50 \%$ higher than plant regrowth, and that if this overuse of the forests continues the state timber enterprises will have nothing to log by the end of the century (Ehrlich and Ehrlich, 1990, p. 117).

\section{Water}

The water in China is in appalling condition, primarily because of pollution (industrial and domestic). Major contributors are the pulp and paper, chemicals, petrochemicals and refining, metalworking, and textile industries and massive concentrations of people. These wastes reach bodies of water either through direct discharge or by leaching from waste dumps.

The pollution effects are exacerbated by China's large population, developing economy, and uneven distribution of rainfall. Water is the one natural resource that is necessary for survival and so when it is polluted, there is less available for domestic (human) usage without treatment and what is available exposes those who use it to disease. Domestic usage includes water for drinking, food preparation, sanitation, washing, cleaning, watering gardens, and the service industry. Domestic water needs have always been modest in relation to industrial needs; however, the quality of the water for domestic use must be high. China is one of the countries in the world suffering from a serious domestic water shortage (FBIS-CHI-90-048, 1990, p. 33). Beijing, for example, is short 7 million gallons of water a day (Yingpu, 1990). One third of the city's water wells have gone dry, and the water table has dropped by as much as $2 \mathrm{~m}$ a year (Linden, 1990, p. 58). Most major urban centers have established quota systems to regulate water consumption. Industry and residents are allowed up to a certain amount of water a month, and those who exceed their quotas must pay fines which can range from double to five times the regular water fees (Bianwu, 1989). Official Chinese estimates, which most likely understate the problem, indicate by the year 2000 the total amount of polluted water will be 80 billion $\mathrm{m}^{3}$ and total water intake will be approximatley 630 billion $\mathrm{m}^{3}$ (JPRS-CST-88-004, 1988, p. 36). The biggest users will be industry and agriculture.

Economic development, combined with an increase in population and pollution, will induce additional shortages of water. Industrial demand for water is expected to be over 80 billion $\mathrm{m}^{3}$ by the year 2000 (JPRS-CST-88-004, 1988, p. 36). Industry uses substantial amounts of water for cooling, processing, cleaning, and removing industrial wastes. China ranks third in the world, after the US and the Soviet Union, for its use of industrial water (World Resources, 1990, p. 174). Although industrial water use returns most of the water back into the water cycle, it is often heavily polluted with chemicals 
(World Resources, 1990, p. 174). Frequent periods of drought and man-made water shortages constrain factories, thus they must operate well below ability. These water shortages impede economic growth. China needs its water for economic growth, but conversely, if China is not careful about that growth, it can destroy the water resources.

China suffers from an uneven distribution of rainfall, which results in severe droughts and floods, especially in agricultural China. Although the droughts and floods are intensified by human abuse of the land, the root cause is the environmental conditions, which tend to fluctuate drastically from year to year and area to area. There is too little rain in the winter and spring and too much in the summer and fall, so water cannot be used effectively (Xiaoping, 1990). The situation is aggravated when gallons of pollutants are dispersed into the rivers, lakes, and groundwater. In addition, the south is rich in water resources, whereas the north, where the major industrial centers are, has only $2 \%$ of the country's water resources (Bianwu, 1989).

By now, one recognizes that the Chinese have a serious water pollution and distribution problem that puts pressure on their quality of life. If steps are not taken immediately, the water supplies will be irreparably polluted by the year 2000 (Xiaoping, 1990). The Chinese use their waterways as dumps for industrial, sewage, and agricultural discharges. Chinese industry dumps approximately 30 billion tons of waste (organic matter and toxic substances) into the water system annually. Only $20 \%$ of waste water is treated and recycled; the other $80 \%$ is discharged into landfills, rivers, lakes, and offshore waters (FBIS-CHI-90-067-S, 1990, p. 18). Technology does exist for the treatment of water and these treatment techniques should have a high priority. Typical treatment options range from screening, grit removal, and primary sedimentation (primary treatment) to biological oxidation (secondary treatment) (World Resources, 1990 , p. 183). There is even an advanced tertiary treatment, which precipitates more solids and removes more nitrogen. First and secondary treatment plants are very common in the United States. Although these sanitation systems are expensive to implement, there are some low-cost alternatives such as pit structures, pour-flush systems, septic tanks, and communal systems (World Resources, 1990, p. 69).

The polluted water in China is adversely affecting people's health and threatening social and economic progress. For instance, several of the lakes around Beijing that are used for recreation are seriously polluted by human waste. Those lakes are discolored and have too much bacteria and suspended substances in them. People still swim in them. The extremely high bacteria count leaves swimmers with various intestinal ailments ("People Still Swim in Beijing's Fouled Lakes," 1989).

China's largest river, the Yangtze, smells bad and is filled with grease, garbage, and other pollutants. Cities and towns along its banks discharge into the river industrial waste and raw sewage. Water quality has deteriorated and the number of fish in the river has decreased substantially ("Yangtze Polluted by Chemicals, Waste," 1989). The river was formerly a source of subsistence for many Chinese. Now fisherman do not 
want to fish in the river; farmers do not want to irrigate their fields with water from the river; and the townspeople do not want to do their laundry with river water or drink the water from the river. In fact residents of Shanghai are encouraged to buy individual water filters for home use.

The Chinese are also polluting their seas, with most of the pollution coming from industrial and municipal sources and being released by ocean dumping, discharge from pipes, and flow from land runoff (referred to as nonpoint pollution because it cannot be traced to a single source). According to government sources, the 80,000 industrial and mining enterprises along the Chinese coastline are contributing $80 \%$ of the total offshore pollutants. Industrial sources of pollution contribute most of the arsenic, mercury, chlorinated hydrocarbons, and other toxic chemicals. Municipal sources of pollution contribute mainly nitrogen and phosphorus, which are contained in sewage; nonpoint pollution is the major source of suspended solids which blocks sunlight to aquatic plants, clog filter-feeding organisms, and carry phosphorus, fecal-coliform bacteria, and other pollutants (World Resources, 1990, p. 182).

Consequently, the seas around China are experiencing a process called eutrophication -the over-enrichment of waters. Eutrophication occurs when an overabundance of nutrients, mainly nitrogen and phosphorus, enter a water body and cause algal blooms and rapid growth of other aquatic plants. When the plants die, decomposing bacteria can deplete the water of oxygen, killing fish and other marine life. There has been a noted increase in the seas around China of an unusual bloom of algae - a phenomenon known as red tides. The toxic waste in the sea causes the sprouting of this algae, which colors the water a reddish-brown and harms marine life. Recent marine monitoring has revealed that some of China's estuaries and harbors that have been heavily polluted by organic compounds and oil leakages have incidents of red tides (Hong, 1990). Last year, China experienced 12 red tides, which did immense damage to the fishing industry ("Red Tides Hitting North Coast," 1990).

The Chinese are learning how best to allocate scarce dollars and trained manpower toward lessening their pollution problems. The Chinese lack equipment to monitor pollution, to regulate pollution, and to use their resources most efficiently to curb pollution. Most equipment that the Chinese have to regulate and monitor pollution is not maintained; parts are missing or broken and they are hardly ever repaired or replaced. Basic concepts like emission controls and discharge regulations are virtually unknown.

China has joined several international environmental bodies, held conferences and symposia on different environmental topics, asked for Western cooperation and assistance on specific environmental issues, started devising a state environmental plan, and in 1988 established a National Environmental Protection Agency (Lide, 1990, p. 32). But drawing up rules and regulations is one thing; enforcing them is another. China's local party bosses are notorious for ignoring any directives from the central government 
that conflict with their desire to make money. The Chinese lack money and technological expertise; currently, environmental protection receives only $0.7 \%$ of China's GNP ("China Holds Seminar on Environmental Protection," 1990, p. 4). But by 1992 spending on environmental protection will increase to 1\% of GNP ("Pollution in Asia," 1990, p. 22). The lack of capital and technological expertise will make it difficult for the Chinese to proceed with any quick environmental changes.

\section{CONCLUSION}

The Chinese government realizes it has some severe environmental problems; furthermore, it knows the nation cannot continue dumping waste at the same rate into water bodies and spewing pollutants into the air. It also discerns the fact that China cannot continue developing and modernizing its economy without some thought to the environment. The Chinese have a long way to go and one gets a definite feeling they do not want to go it alone. The Chinese will continue to take part in various environmental functions because it is good public relations, but the government's willingness to take major steps will be linked to its ability to receive financial and technological assistance from the developed world.

The Chinese are currently looking to the West and will probably want to increase interactions. Areas that require vast amounts of money and technological expertise (toxic waste disposal, water treatment plants, and efficient energy development techniques) will be high on the list for western assistance. The Chinese believe the West has a responsibility to help them because they are a poor country and environmental destruction observes no national boundaries. Furthermore, it is felt the West owes it to China because of Western exploitation in the 19th century.

The Chinese are faced with a trade-off between environmental protection and economic growth and development, a trade-off common to many developing countries, (e.g., India) and will most often choose economic growth.

The Chinese government would like to accumulate as much scientific and technological information from the West as possible. In the last year, many Western countries were slow to help because of the events at Tiananmen Square and the blatant repression of human rights throughout the country. No matter who helps them or how much aid is sent, the bottom line will be: China will take most seriously those environmental problems that have the greatest negative impact on its developing economy.

Because the Chinese are eager to acquire basic technology and information and the US is an available source, the US may be able to take advantage of the present climate in China and offer assistance. 


\section{ACKNOWLEDGMENTS}

The author thanks the following LANL personnel for assistance with this report:

Nerses H. Krikorian, IT-DO, Caroline F. V. Mason, IT-3, LaVerne Rodriguez, IT-3, and Rodney S. Thurston, IT-3. 


\section{REFERENCES}

Baoxia, Z. (23 April 1990) "Efforts to End Fluorine Toxicosis," China Daily.

Bian, Y. (19 July 1989) "Acid Rain Threatens Crops and Forests in Some Areas of China," China Daily.

Bianwu, L. (8 September 1989) "Cities Battling A Water Shortage," China Daily.

Cankao, J. (February March 1990) "Less Dust in Beijing," Beijing Review.

Carpenter, R. A. (1990) "Foreign Assistance for China's Environment?" Environment, Science, and Technology: American Chemical Society, Vol. 24, No. 6.

"Census Finds 1.16 Billion; Annual Rise 17 Million," (31 October 1990) China Daily.

Center For International Research, US Census Bureau.

Chengwen, G. (5 January 1990) "Dearth of Energy and Raw Materials Expected to Last," China Daily.

Chengwen, G. (21 July 1990) "Measures to Give People More Energy," China Daily.

"China Holds Seminar on Environmental Protection," (9 March 1990) Global Environmental Change Report, Vol.II, No. 5.

"China Says Nuclear Accidents Killed 20," (6 August 1989) Associated Press Report, Los Alamos Monitor.

"Chinese Mining," (23 April 1983) The Economist.

Chua-Eoan, H. G. (2 October 1989) "A Day in the Life of China," Time.

Ehrlich, P. R. and Ehrlich, A. H. (1990) The Population Explosion, Simon and Schuster: New York.

Elmer-Dewitt, P. (2 January 1989) "Preparing for the Worst," Time.

Ember, L. R. (16 April 1990) "Pollution Chokes East-bloc Nations," Chemical and Engineering News.

English, P. W. (1984) World Regional Geography, John Wiley \& Sons: New York. 
"FBIS-CHI-89-009-S (12 January 1989) "Energy Industry Improves Efficiency."

FBIS-CHI-90-044 (6 March 1990) "Forestry Minister Speaks."

FBIS-CHI-90-048 (12 March 1990) "Chen Junsheng Urges Water-Saving Agriculture."

FBIS-CHI-90-067-S (6 April 1990) "Environmental Control Report Issued at Conference."

Hanchen, Wang. JPRS-CST-88-004 (16 February 1988) "Clean Air Predicted: Pollution from Coal Burning Still a Problem."

Hong, L. (23 November 1989) "Lights Go On, Off in Beijing," China Daily.

Hong, L. (17 February 1990) "Pollution Laws Help to Clean Up China Seas," China Daily.

Hongqi, Z. (24 April 1990) "China Looking to its Own West for Energy Bonanza," China Daily.

Huang, J. P. (March-April 1991) "Fueling the Economy," The China Business Review.

Lee, D. B. (December 1988) "Oil in the Wilderness an Arctic Dilemma," National Geographic.

Lemonick, M. D. (2 January 1989) "Feeling the Heat," Time.

Lide, V. (July-August 1990) "Perils of Pollution," The China Business Review.

Linden, E. (20 August 1990) "The Last Drops," Time.

*JPRS-CST-88-004 (16 February 1988) "Experts Forecast Severe Water Pollution by the Year 2000."

JPRS-CST-89-017 (31 August 1989) "Acid Rain Situation Seen Worsening."

JPRS-TND-88-017 (21 September 1988) "Head of Nuclear Society on Nuclear Development."

*Foreign Broadcast Information Service (FBIS) and Joint Publications Research Service (JPRS) are published through the National Technical Information Service (NTIS), 5285 Port Royal Road, Springfield, Virginia 22161, (703) 487-4630. 
Kan, R. (25 May 1990) "State Stresses Power Generator Production," China Daily.

MacDougall, C. (May 1990) "The Ethnic Minorities Threaten," World Press Review.

McGregor, J. (3 may 1991) "U.S. Facing Tough Task on China Trade," The Wall Street Journal.

McKenzie, E. (July 1990) Personal Communication.

Naughton, B. (May-June 1991) "Economic Directions for the '90s," The China Business Review.

"Nuclear Plant Makes Energy and Aids Economy," (10 October 1989) China Daily.

"Oil Output Increases But Industry in Trouble," (11 July 1989) Xinhua.

"Oil Produced," (3 April 1990) China Daily.

Pearce, F. (8 July 1990) "The Giants that are Stalking the Earth," Guardian Weekly.

"People Still Swim in Beijing's Fouled Lakes," (9 August 1989) China Daily.

"Pollution In Asia," (6 October 1990) The Economist.

"Pollution Worsening in Sichuan," (24 August 1989) China Daily.

"Red Tides Hitting North Coast," (7 February 1990) China Daily.

Steger, W. and Bowermaster, J. (1990) Saving the Earth, Alfred A. Knopf, Inc.: New York.

Toufexis, A. (2 January 1989) "Too Many Mouths," Time.

"Trans-American Chemical Corporation," (September-October 1989) The China Business Review.

"Two Ways to Cope," (December 1988) National Geographic.

Tyson, J. L. (5 September 1990) The Christian Science Monitor.

Vernor, B. (March-April 1990) "Oil," The Chind Business Review. 
"World List of Nuclear Power Plants," (August 1990) Nuclear News.

World Resources: 1990-91 (1990) Oxford University Press: Oxford.

Xiang, H. (23 April 1990) "China Invests in Two Hydro Stations," China Daily.

Xiaoping, Y. (22 February 1990) "Scientists Prompt China to Control Water Pollution," China Daily.

"Yangtze Polluted by Chemicals, Waste," (9 August 1989) China Daily.

Yingpu, Q. (5 April 1990) "UN Agrees Aid Deals with China," China Daily.

Zai, S. and Qide, C. (30 October 1989) "First Nuclear Plant Faces Critical Test," China Daily. 

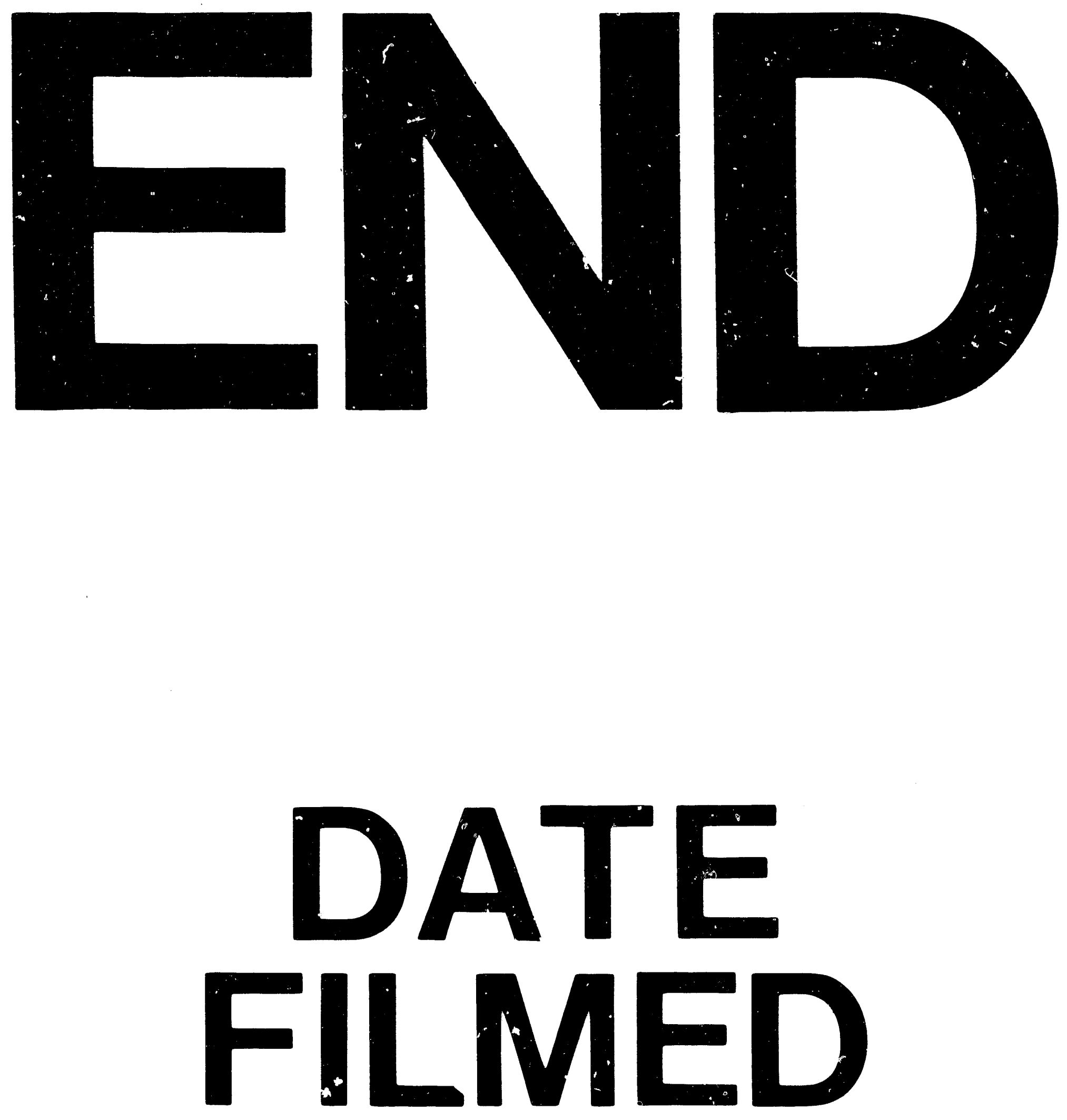

I

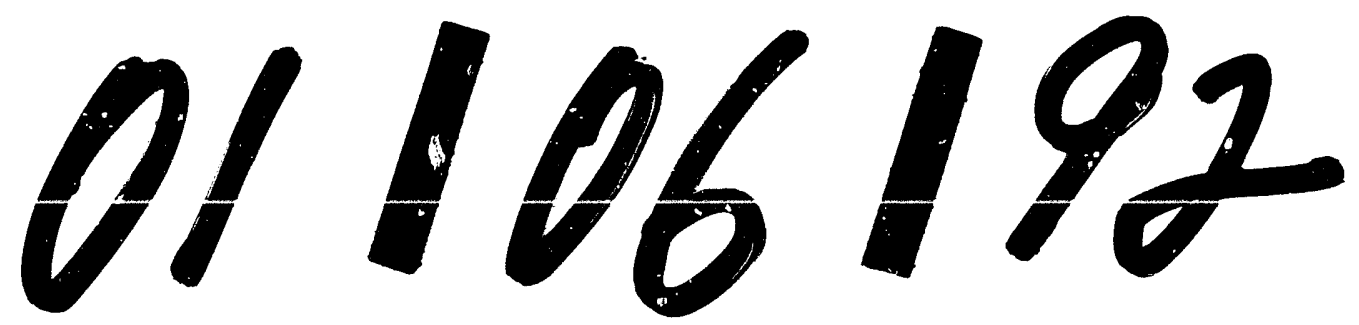


